\title{
Food Security Status During The Covid-19 Pandemic Among Vulnerable Groups In Keiyo South, Elgeyo Marakwet County, Kenya
}

\author{
${ }^{1}$ Ouma, Peter O., ${ }^{2}$ Ouma Robinson ${ }^{3}$ Mugalavai, Violet K., ${ }^{4}$ Onkware, Augustino O. \\ ${ }^{1}$. Center for Teacher Education, School of Education, University of Eldoret Box 1125 Eldoret \\ ${ }^{2}$. Department of Business Studies, Rongo University, Kenya \\ ${ }^{3}$. School of Agriculture, Department of Family Consumer Sciences, University of Eldoret, Kenya. \\ 4. School of Science, Rongo University, Kenya. \\ DOI: 10.29322/IJSRP.11.02.2021.p11083 \\ http://dx.doi.org/10.29322/IJSRP.11.02.2021.p11083
}

\begin{abstract}
Health guidelines to manage the COVID-19 pandemic could have led to unintended changes in states and processes that affect food systems, food security, and nutrition. The study conducted in Elgeyo Marakwet County, Kenya focused on the impacts of the pandemic on food security and post-harvest losses. A cross-sectional survey was used to gather information on food security concerns from household heads in Keiyo South. Questionnaires were administered to 400 household heads derived from 99,861 households. Analysis of variance results indicated significant $(\mathrm{p}<0.01)$ differences among the vulnerable groups such as infants of less than six months $(F=4.665)$ pregnant women $(\mathrm{F}=6.474)$ and people living with chronic diseases ( $F=4.838$ ). According to World Bank report of 2020, the pandemic has resulted in an economic recession with significant loss of livelihoods and income and the consequent decline in purchasing power. Household income during the pandemic was correlated to diet change especially among vulnerable groups. There was a significant correlation $(\mathrm{p}<0.01)$ between household income during the COVID-19 pandemic and diet change for infants $(r=0.457)$, breastfeeding mothers $(r=0.609)$, pregnant women $(r=0.695)$ and those with chronic disease $(r=0.577)$. A relationship between household income and diet change for children between the age of six (6) months and five (5) years $\mathrm{p}$ $(\chi 2=27.657$, df 8$)=0.001$ at $\alpha 0.05$. Because of the disruption of household income occasioned by the pandemic, external interventions should target increasing income for households with the most vulnerable persons for improved food and nutrition security.
\end{abstract}

Index Terms- Covid-19 pandemic, food security, vulnerable groups, post-harvest losses

\section{INTRODUCTION}

$\mathrm{T}$ he COVID-19 pandemic has led governments to impose public health measures that have led to changes in several aspects of life affecting food systems and food security and nutrition whereof causing disruptions to food supply chains, loss of income and livelihoods, increasing inequality, interference with social protection programs, and uneven food prices (Clapp
\& Moseley, 2020; Laborde et al., 2020). Before the pandemic, instances of chronic hunger had already been reported to increase. In 2019 for example, close to 135 million people across 55 countries experienced severe hunger due to job losses and the subsequent reduction in income as well as overstretched and disrupted food systems. The pandemic is likely to cause global economic recession that could lead to an estimated 100 million people across the globe being pushed into extreme poverty (FAO \& WFP, 2020). It will lower both productivity and production, and accessibility (Committee on World Food Security (CWFS), 2020). Export restrictions on key staple food during the initial stages of the outbreak affected the livelihoods of food producers who depended on international export (Laborde et al., 2020). Lockdown measures have caused disruptions in food supply chains thus affecting availability, pricing, and quality of food. The closure of food outlets such as restaurants resulted in a drop in demand for perishable foods such as potatoes, dairy products, and fresh fruits (Barrett (2020). The exportation and importation of food through international trade have also been affected by the lockdown measures. According to the report UN, (2020), it was estimated that one-third of the food system livelihoods are at risk due to the pandemic.

The pandemic has resulted in an economic recession with significant loss of livelihoods and income and the consequent decline in purchasing power and food insecurity (World Bank, 2020). It has led to a loss of 400 million full-time jobs globally during the second quarter of 2020 (ILO, 2020). Declining income brings about reduced food market which affects livelihoods of food producers and food system workers. Gender inequality and the risk of women facing domestic violence due to confinement at home have increased. The prominent role of women in food systems such as food producers, managers of farms, food traders, wageworkers, and as primary actors of ensuring household food security and nutrition has been affected(FAO, 2020; WHO, 2020). In addition, it has also disrupted social protection programs that have in turn affected food security (CWFS, 2020). The closure of schools, for instance, resulted in the loss of school feeding programs, in which, according to WFP (2020), 370 million school-going children lost access to school meals. The closure of informal markets, deemed COVID-19 
transmission zones, robbed a large population in Kenya their source of food and livelihood (Battersby, 2020).

The Higher Level Panel of Experts (HLPE), 2020 Global Narrative Report highlights four dimensions of food security (availability, access, stability, and utilization). In terms of food availability, cereal production in low-income countries is highly susceptible to disease outbreak. Farming in these countries is largely on small-sized farms, labor-intensive as well as femaledominated. The pandemic has affected people's ability to access food more so in developing nations given their inadequate capacity to provide sufficient social safety nets (Gerard et al., 2020). As such, the decline in income due to the pandemic equals low spending on food. This is true especially to low-wage workers, small-scale farmers, informal traders, and hawkers where an increase in food prices directly affects households' ability to access food.

The study was conducted in Keiyo South sub-county Elgeyo Marakwet County located in the North Rift region of Kenya. According to KNBS, (2019), Elgeyo Marakwet county has a population of 454,480 people, 99,861 households, and land covering an area of $3,032 \mathrm{Km}^{2}$. The county borders West Pokot to the North, Baringo to the East, Trans Nzoia to the North West, and Uasin Gishu to the West. The County is further subdivided into four sub-counties namely Keiyo North, Keiyo South, Marakwet East, and Marakwet west. Keiyo South Sub-county, which was purposively sampled since it had been flagged for food insecurity even before COVID-19 has a population of 120,750 people, 27,029 households, and an area of $897 \mathrm{Km}^{2}$ (GoK, 2018). The study sought to determine the impacts of the pandemic on food security, food security concerns, to determine the impacts of the pandemic on post-harvest losses, and to establish ways to improve agricultural production amidst the pandemic.

\section{METHODOLOGY}

A cross-sectional survey was used for the research. The target populations for the study were the household heads in Elgeyo Marakwet County. The target population in Keiyo South was stratified into six wards (Kabiemit, Soy South, Soy North, Metkei, Chepkorio, and Kaptarakwa wards) out of which four wards namely Kaptarakwa, Soy North, Metkei, and Chepkorio were sampled randomly. Figure 1 shows the study area 

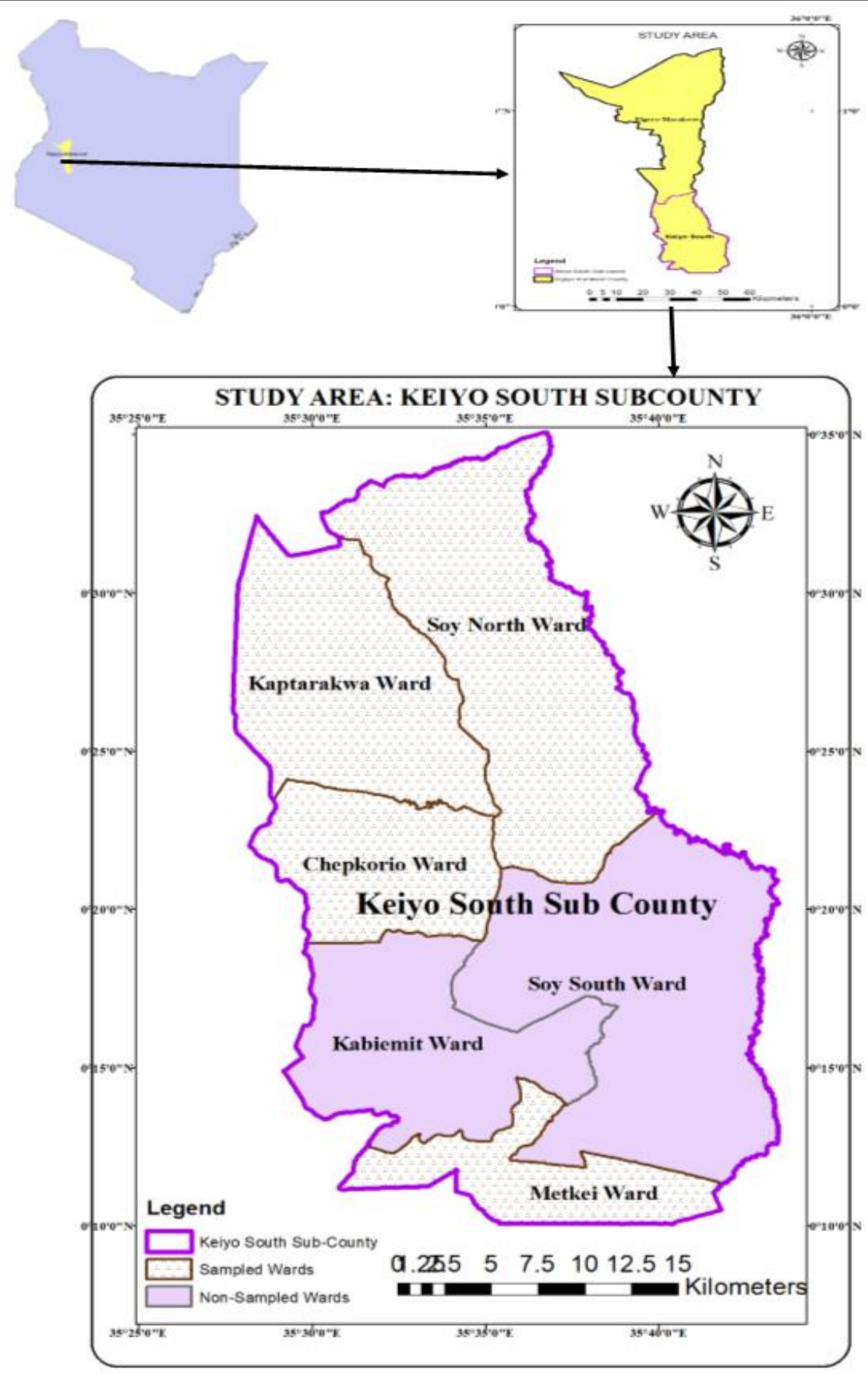

Fig 1: Map of Keiyo South Sub County

Information on the COVID-19 related food security concerns was collected by the use of questionnaires. Respondents were identified using random sampling and COVID-19 safety precaution measures were followed during data collection. The sample size was determined according to Yamane, (1967) since the study area population was finite as shown in the formula $n=\frac{N}{1+N(e)^{2}}$

$\begin{array}{ccl}\text { Where: } n & - & \text { Sample Size } \\ N & - & \text { Population Size } \\ e & - & \text { Level of Precision }\end{array}$

This publication is licensed under Creative Commons Attribution CC BY.
The sample size of 400 was distributed proportionally across the four sampled wards and then respondents sampled linearly after every tenth household.

\section{RESULTS AND DISCUSSIONS}

The main economic activities of the household heads were categorized into six. The main economic activity is farming (460 respondents accounting for $80.99 \%)$ and business (15 respondents accounting for $15.49 \%$ ) with the majority of the residents (41.63\%) earning less than Kshs 5,000 a month compared to only $8.57 \%$ who earn above Kshs 20,000 a month. 
Other economic activities in the area included teaching $2.1 \%$, technical work $0.70 \%$, police officers, and nurses at $0.35 \%$. The population is largely youthful since the mean age is 43 years. Males were $58.1 \%$ while female made $41.9 \%$ of those aged 43 years. The average household size was six (6) individuals. Among the respondents $41.6 \%$ had primary level education, $31.4 \%$ secondary education level, $18.8 \%$ tertiary education level (college), $7.1 \%$ university education level, and $1.2 \%$ did not attend formal education. This thus points out the importance of socio-economic characteristics in understanding how the pandemic is likely to impact upon the population in terms of food security.

\section{Determination of the impacts of the COVID-19 pandemic on food security}

A recent statement by the UN Secretary-General has warned of a looming global food emergency (FAO \& WFP, 2020a). Due to the known condition of Keiyo South in terms of food security, it was necessary to establish if there was any correlation between the income of the household during the pandemic and the effect on vulnerable groups in the community. From the GoK, 2018 (Elgeyo Marakwet County CIDP 2018 2022), the vulnerable groups in terms of food security are identified as pregnant women, breastfeeding mothers, the elderly, those with chronic disease and infants below five years of age. Table 1 shows an analysis of the correlation between household monthly income and diet change among the vulnerable groups in the study area.

Table 1: Pearson's correlation (2-tailed) between household monthly income and diet change among vulnerable groups during COVID-19 pandemic

\begin{tabular}{lll}
\hline Control variable & Value & $\begin{array}{l}\text { Sig(2- } \\
\text { tailed) }\end{array}$ \\
\hline Diet change in infants to children & 0.457 & 0.000 \\
\hline
\end{tabular}

\begin{tabular}{|c|c|c|}
\hline \multicolumn{3}{|l|}{ below 6 months } \\
\hline $\begin{array}{l}\text { Diet change in children of } 6 \\
\text { months to } 5 \text { years }\end{array}$ & 0.398 & 0.000 \\
\hline Diet change in pregnant women & 0.695 & 0.000 \\
\hline $\begin{array}{l}\text { Diet change in breastfeeding } \\
\text { mothers }\end{array}$ & 0.609 & 0.000 \\
\hline $\begin{array}{l}\text { Diet change in those of age } 65 \\
\text { vears and above }\end{array}$ & 0.577 & 0.000 \\
\hline $\begin{array}{l}\text { Diet change in those with chronic } \\
\text { disease }\end{array}$ & 0.501 & 0.000 \\
\hline
\end{tabular}

There was a significant $(\mathrm{p}<0.01)$ correlation between household income during the COVID-19 pandemic and dietary change for infants $(r=0.457)$, breastfeeding mothers $(r=0.609)$, pregnant women $(\mathrm{r}=0.695)$ and those with chronic disease $(\mathrm{r}=$ 0.577). Export restrictions on staple food such as wheat and rice have resulted in an escalation of local food prices thus affecting food system stability and the willingness of people and firms to invest in food production (Espitia et al., 2020; FAO, 2020c; UNCTAD, 2020). According to Ekumah et al., (2020), low and middle-income countries are more likely to be impacted upon by the pandemic than the developed nations. In low and middleincome countries where $50-80 \%$ of income is spent on food, the change in diet toward more processed foods and fewer fruits and vegetables has largely contributed to malnutrition (Micha et al., 2020). Descriptive statistics for the relationship between household monthly income and diet change for children between the age of six (6) months old and five (5) years old was conducted to determine the impact of the pandemic on food security in the study area. Figure 2 is a visual representation of the relationship between dietary change for Children between the age of six (6) months and five (5) years by household monthly income due to pandemics. 


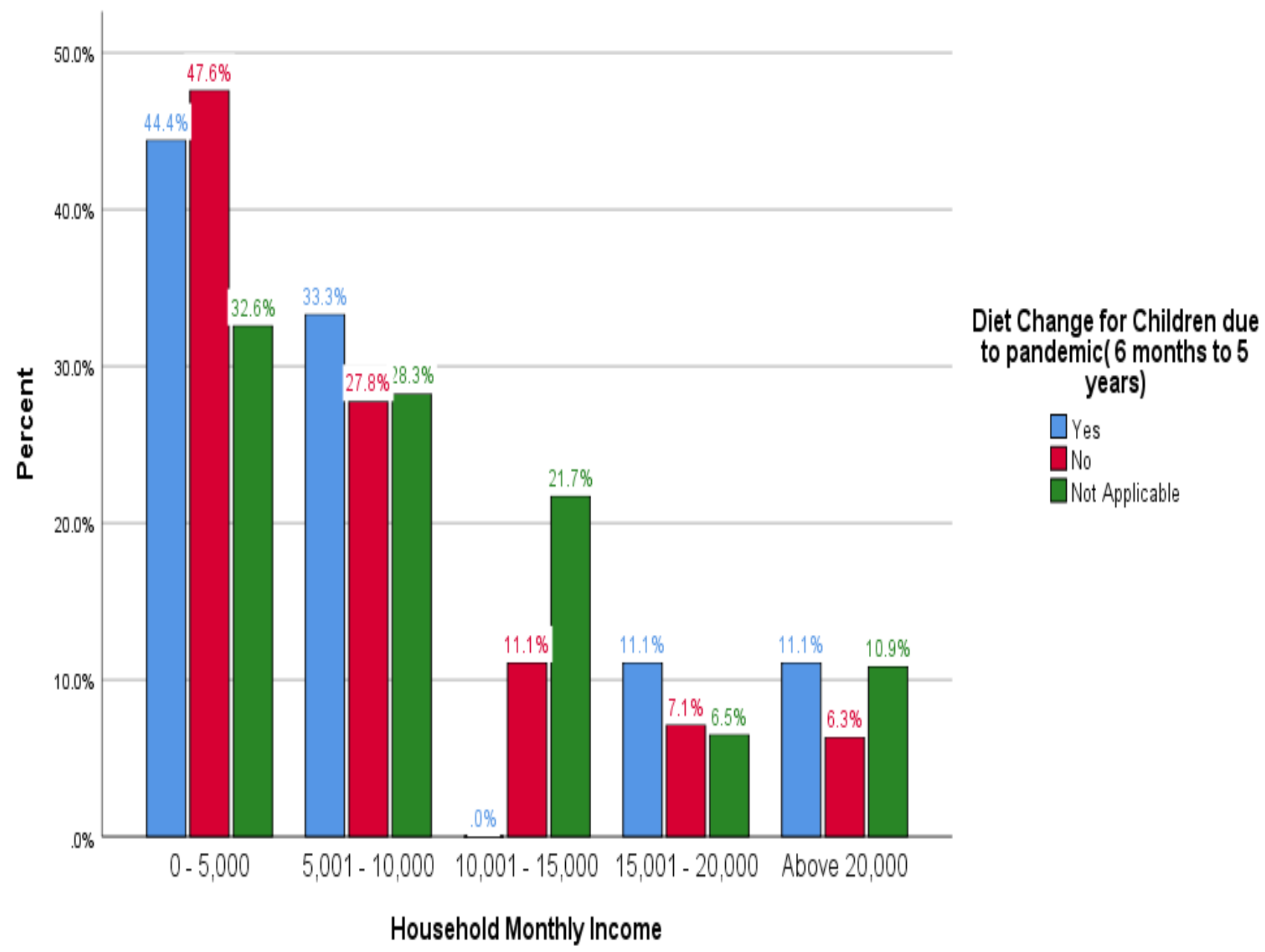

Fig 2: Effect of Diet Change on Children due to Pandemic by Household Income

The effect due to of the pandemic on diet changes was greatest for households earning below Kshs. 5,000 with 44.4\% and $33.3 \%$ of children from families earning a monthly income of between Ksh 5,001 and Ksh 10,000. The effect appeared to reduce as the household income increased. The findings of Chi-
Square test on household income and diet change for children between the age of six (6) months and five (5) years are shown in table 2 .

Table 2: Chi-Square Tests on household income and diet change on children aged 6 months to 5 years

\begin{tabular}{|l|l|l|l|}
\hline & Value & df & Asymp. Sig. (2-sided) \\
\hline Pearson Chi-Square & $27.657^{\text {a }}$ & 8 & .001 \\
Likelihood Ratio & 34.092 & 8 & .000 \\
Linear-by-Linear Association & 7.150 & 1 & .007 \\
N of Valid Cases & 490 & & \\
\hline
\end{tabular}

a. 2 cells (13.3\%) have expected count less than 5. The minimum expected count is 3.97 .

A significant relationship between the two stated variables $\mathrm{p}\left(\chi^{2}=27.657\right.$, df 8$)=0.001$ at $\alpha 0.05$ These changes were more prominent in the lower-income group (those that earn below Kshs. 5,000 per month). This shows that the pre-existing vulnerable population (such as the lowest income earners in the study area were more likely to face dire consequences of food insecurity. According to Chepwambok et al., (2020), Elgeyo Marakwet County was found to experience food insecurity even before the Covid-19 pandemic. Arror ward was found to be more food insecure indicating up to 100 percent incidents of food insecurity. These disadvantaged groups have little capacity to

deal with adverse consequences of the pandemic due to limited access to basic resources, better employment opportunities, safety nets, and resources to enable them to rebuild livelihoods that have been overstrained by the pandemic.

Analysis of variance was conducted to determine the difference in food security among the vulnerable groups based on access to food, variety of food, and rationing of food. There was significant $(\mathrm{p}<0.01)$ difference in the level of food security among the vulnerable groups. ANOVA results indicated significant differences among the vulnerable groups namely: infants of less than 6 months $(\mathrm{F}=4.665$ and $\mathrm{P}=.010)$ pregnant 
women $(\mathrm{F}=6.474$ and $\mathrm{P}=.002)$ and people living with chronic diseases $(\mathrm{F}=4.838$ and $\mathrm{P}=.008)$. Based on the variety of food among the vulnerable groups the analysis indicated that for infants of less than 6 months (F-value of 29.775 and p-value of $0.000)$ pregnant women (F-value of 24.744 and p-value of 0.000 ) and people living with chronic diseases (F-value of 44.428 and $\mathrm{p}$ value of 0.000$)$. Based on food ration among the vulnerable groups, the ANOVA results indicated that for infants of less than 6 months (F-value of 1.121 and p-value of 0.290 ) pregnant women (F-value of 0.56 and p-value of 0.813 ), and people living with chronic diseases (F-value of 10.194 and p-value of 0.001 ).
In the study area where most of the residents are farmers, a decline in food demand because of declining income due to the pandemic, food producers, and food system workers' livelihood are most likely affected. According to the UN (2020), approximately one-third of food system livelihoods are at risk due to the pandemic. Torero (2020), estimated the loss of 451 million jobs in the food system as a result of the pandemic. Table 3 shows the difference in household food security index by vulnerable groups based on access to food.

Table 3: ANOVA results showing the difference in household food security index by vulnerable groups based on access to food

\begin{tabular}{|c|c|c|c|c|c|c|}
\hline & & $\begin{array}{l}\text { Sum } \\
\text { Squares }\end{array}$ & $\mathrm{f}$ Df & $\begin{array}{l}\text { Mean } \\
\text { Square }\end{array}$ & $\mathrm{F}$ & Sig. \\
\hline $\begin{array}{l}\text { Diet change for infants due to } \\
\text { pandemic (less than } 6 \text { months } \\
\text { old) }\end{array}$ & $\begin{array}{r}\text { Between Groups } \\
\text { Within Groups } \\
\text { Total }\end{array}$ & $\begin{array}{l}10.310 \\
569.119 \\
579.429\end{array}$ & $\begin{array}{l}2 \\
515 \\
517\end{array}$ & $\begin{array}{l}5.155 \\
1.105\end{array}$ & 4.665 & .010 \\
\hline $\begin{array}{l}\text { Diet Change for Children due to } \\
\text { pandemic( } 6 \text { months to } 5 \text { years) }\end{array}$ & $\begin{array}{c}\text { Between Groups } \\
\text { Within Groups } \\
\text { Total }\end{array}$ & $\begin{array}{l}1.349 \\
617.793 \\
619.142\end{array}$ & $\begin{array}{l}2 \\
519 \\
521\end{array}$ & $\begin{array}{l}674 \\
1.190\end{array}$ & 566 & .568 \\
\hline $\begin{array}{l}\text { Diet change for Pregnant } \\
\text { women due to pandemic }\end{array}$ & $\begin{array}{r}\text { Between Groups } \\
\text { Within Groups } \\
\text { Total }\end{array}$ & $\begin{array}{l}12.581 \\
504.262 \\
516.843\end{array}$ & $\begin{array}{l}2 \\
519 \\
521\end{array}$ & $\begin{array}{l}6.290 \\
.972\end{array}$ & 6.474 & .002 \\
\hline $\begin{array}{l}\text { Diet change for breastfeeding } \\
\text { woman due to pandemic }\end{array}$ & $\begin{array}{c}\text { Between Groups } \\
\text { Within Groups } \\
\text { Total }\end{array}$ & $\begin{array}{l}8.565 \\
567.711 \\
576.276\end{array}$ & $\begin{array}{l}2 \\
519 \\
521\end{array}$ & $\begin{array}{l}4.283 \\
1.094\end{array}$ & 3.915 & .021 \\
\hline $\begin{array}{l}\text { Diet change for elderly people } \\
\text { due to pandemic }(65+\text { years old })\end{array}$ & $\begin{array}{c}\text { Between Groups } \\
\text { Within Groups } \\
\text { Total }\end{array}$ & $\begin{array}{l}3.143 \\
591.288 \\
594.431\end{array}$ & $\mid \begin{array}{l}2 \\
517 \\
519\end{array}$ & $\begin{array}{l}1.572 \\
1.144\end{array}$ & 1.374 & .254 \\
\hline $\begin{array}{l}\text { Diet change for people with } \\
\text { chronic diseases due to } \\
\text { pandemic }\end{array}$ & $\begin{array}{r}\text { Between Groups } \\
\text { Within Groups } \\
\text { Total }\end{array}$ & $\begin{array}{l}8.753 \\
469.515 \\
478.268\end{array}$ & $\begin{array}{l}2 \\
519 \\
521\end{array}$ & $\begin{array}{l}4.377 \\
.905\end{array}$ & 4.838 & .008 \\
\hline
\end{tabular}

$\mathrm{p}<0.01$

Other vulnerable groups that experienced a diet change in the study area due to the pandemic were pregnant women, breastfeeding mothers, elderly people, and people living with chronic diseases. According to Health Surveillance report for Elgeyo Marakwet County published in 2015, the chronic diseases include HIV (2.2\% on antiretroviral drugs), malaria (positivity rate at $10 \%$ against the national rate of $41 \%$ ) and tuberculosis $(0.2 \%)$. The county government on expenditure on health is Ksh 2159 against the national expenditure of Ksh 1585 per capita. Besides, there was a significant relationship between food insecurity and losses incurred at different management processes.

Further analysis was carried out to determine the most food insecure among the vulnerable groups based on access to food. This could determine the group that is the greatest danger and requires immediate intervention. Post Hoc tests indicated that the most vulnerable groups were infants of less than 6 months, pregnant women, and people living with chronic diseases. Table 4 shows the results of the Turkey's LSD Post hoc tests. Therefore, interventions should target these three groups for the improved food security situation. The risk of food insecurity is even greater in a region with lower population density (KNBS, 2019) such as the study area as women are at greater risk of exposure to COVID-19 as they are in the frontline in the caregiving roles for the sick, children, and the elderly (Moseley, 2020). 
Table 4: Turkey's LSD Post hoc test on household food security based on vulnerability

\begin{tabular}{|c|c|c|c|}
\hline Dependent Variable & $\begin{array}{l}\text { Mean } \\
\text { Difference (I- } \\
\text { J) }\end{array}$ & $\begin{array}{l}\text { Std. } \\
\text { Error }\end{array}$ & Sig. \\
\hline Diet change for infants due to pandemic (less than 6 months old) & $.254^{*}$ & .096 & .009 \\
\hline Diet change for Pregnant women due to pandemic & $.271^{*}$ & .090 & .003 \\
\hline Diet change for breastfeeding woman due to pandemic & $.210^{*}$ & .095 & .028 \\
\hline Diet change for elderly people due to pandemic $(65+$ years old) & .023 & .098 & .813 \\
\hline Diet change for people with chronic diseases due to pandemic & $.199^{*}$ & .087 & .022 \\
\hline
\end{tabular}

*. The mean difference is significant at the 0.05 level.

Gender inequalities are also one of the socioeconomic characteristics that have been affected by the pandemic. Though with a small margin, the number of females in the study area was lower compared to males. In the wake of the pandemic, this is likely to impact negatively on the food security of the study area. McLaren et al. (2020) \& Power (2020), state that the COVID-19 pandemic has led to more gender inequalities as women are charged with extra mandates as frontline health and food system workers, unpaid care work, and community work during lockdowns. Further, women face the risk of domestic violence as a result of confinement at home brought about lockdown measures to contain the spread of the pandemic (FAO, 2020; WHO, 2020). The outbreak of the COVID-19 pandemic has further exacerbated the global food insecurity cases that have been rising over the past four years mainly caused by conflicts, climate change, and economic recession.

\section{Determination of food security concerns caused by the COVID-19 pandemic}

Government measures such as import restriction and limitation of the movement have disrupted entire food chains from production, processing, transportation, marketing as well as the movement of livestock fundamental to the survival of pastoralists. Closed markets, export restrictions, and delays have collectively jeopardized the food chains globally. The impact is even more prominent to farmers producing perishable goods such as fruits and vegetables hence result in losses and consequently reduced wages. Besides, food shortages due to disruption of the supply chain, labor shortages resulting from self-quarantine have further exacerbated food shortage.

From the findings, $24.81 \%$ and 15.895 of the respondents were extremely and moderately concerned about the risk of the households not having sufficient food supply respectively. Due to speculation and concern over the risk of food shortage, most households tended to lead to the excessive purchase of food items. Nonetheless, even among those who were somewhat, slightly, and not at all concerned over household food security still had $4.26 \%, 12.79 \%$, and $1.9 \%$ of them purchasing food items above normal purchases respectively. This worsens food insecurity given that diets poor in antioxidants, obtained from fresh fruits and vegetables would most likely increase oxidative stress and inflammation (Mattioli et al., 2020). A study by Laborde et al., (2020) suggests that poor households such as the ones in this study area (as evident by the monthly household income) are likely to shift their spending away from fresh fruits and vegetables (antioxidants) with high micronutrient content to less nutrient-rich staple foods as a direct result of the pandemic. Data on the level of concern among the residents and instances of excessive purchasing of food in the household was sought and the results are in figure 3. 


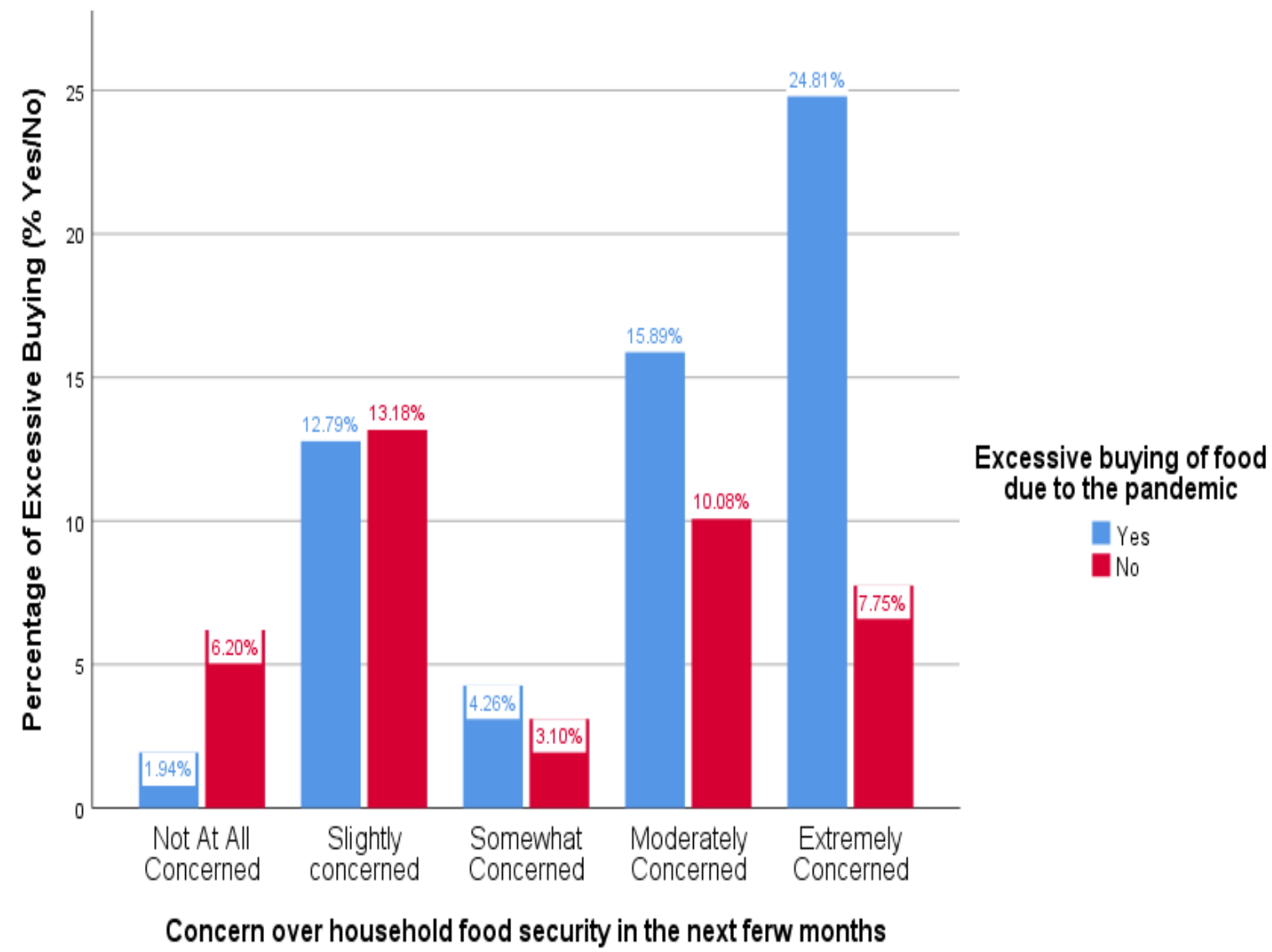

Fig 3: Concern regarding buying excessive food due to pandemic

The shutdown of informal markets in developing nations as a measure to curb the pandemic has severely impacted key food sources and livelihoods for the poor. The households face food challenges such as access to less variety of food, access to food of lesser quality, a limited quantity of food, food rationing in the household and moving long distances to access food. This is due to the impact of the COVID-19 pandemic to the efficient operation of food value chains and the movement of agricultural products critical to food security and nutrition. This in turn impacts the ability of women to execute their prominent roles in food systems as primary actors of ensuring household food security and nutrition, food producers, farm managers, food traders and wageworkers.

A Chi-Square test was further conducted to test for the relationship between concern over food security and purchasing of food in large quantities. Findings showed a significant relationship between concern over food security and purchasing food staffs in large quantities to avert food insecurity $\mathrm{p}\left(\chi_{2}=\right.$ 47.725 , df 4$)=0.000$ at $\alpha 0.05$. The greatest challenge experienced by the locals was access to less variety of food $34 \%$, access to quality food $18 \%$, limited quantity of food $17 \%$, rationing of food in household $14 \%$, driving or walking long distances to acquire food $12 \%$ and food rationing by the local government $5 \%$ as the least. This study showed a significant relationship between household concern over food security and purchasing food staffs in large quantities to avert food insecurity.

\section{Assessment of the impacts of COVID-19 pandemic on post- harvest losses}

According to Barrett (2020), lockdown measures to contain the pandemic affected the availability, pricing and quality of food. The closure of food outlets such as restaurants resulted in a sharp decline in demand for certain perishable foods among them dairy products, potatoes and fresh fruits (Lewis, 2020). As the pandemic continued to spread in many countries across the globe in the period between March and May of 2020, there were widespread reports of food being dumped or ploughed back into the fields due to collapse in demand and difficulty accessing markets (Yaffe-Bellany \& Corkery, 2020).

Respondents reported post-harvest losses in several agricultural produce that is grains (cereals \& starchy foods), livestock products, fruits, vegetables and legumes. It was evident that the highest cause for post-harvest losses was experienced in legumes followed by livestock products and grains where $46.9 \%$, $40.5 \%$ and $39.7 \%$ post-harvest losses respectively. With the existing COVID-19 pandemic, these losses were a strong indicator to supply chain disruption factors such as difficulty accessing the market, limited post-harvest handling knowledge, difficulty accessing extension services and poor storage. Farmers with inadequate storage facilities such as cold storage were more affected as they possessed food they could not sell. As international borders were closed for trade due to lockdown, demand for certain foods dropped. Farmers reliant on the international market for their products especially those producing perishable foods got severely affected (Clapp \& G. Moseley, 
2020). The reasons for post-harvest losses were limited postharvest handling knowledge $(65.2 \%$ of the households), difficulty-accessing market $(62.7 \%)$, and difficulty accessing extension services $(52.7 \%)$ and poor storage $(31 \%$ of the households). Mitigation measures target education of farmers on handling post harvests as well as intensified agricultural extension for value addition of crop produce. The figure 4 presents the responses of farmers with respect to post-harvest losses on food products.

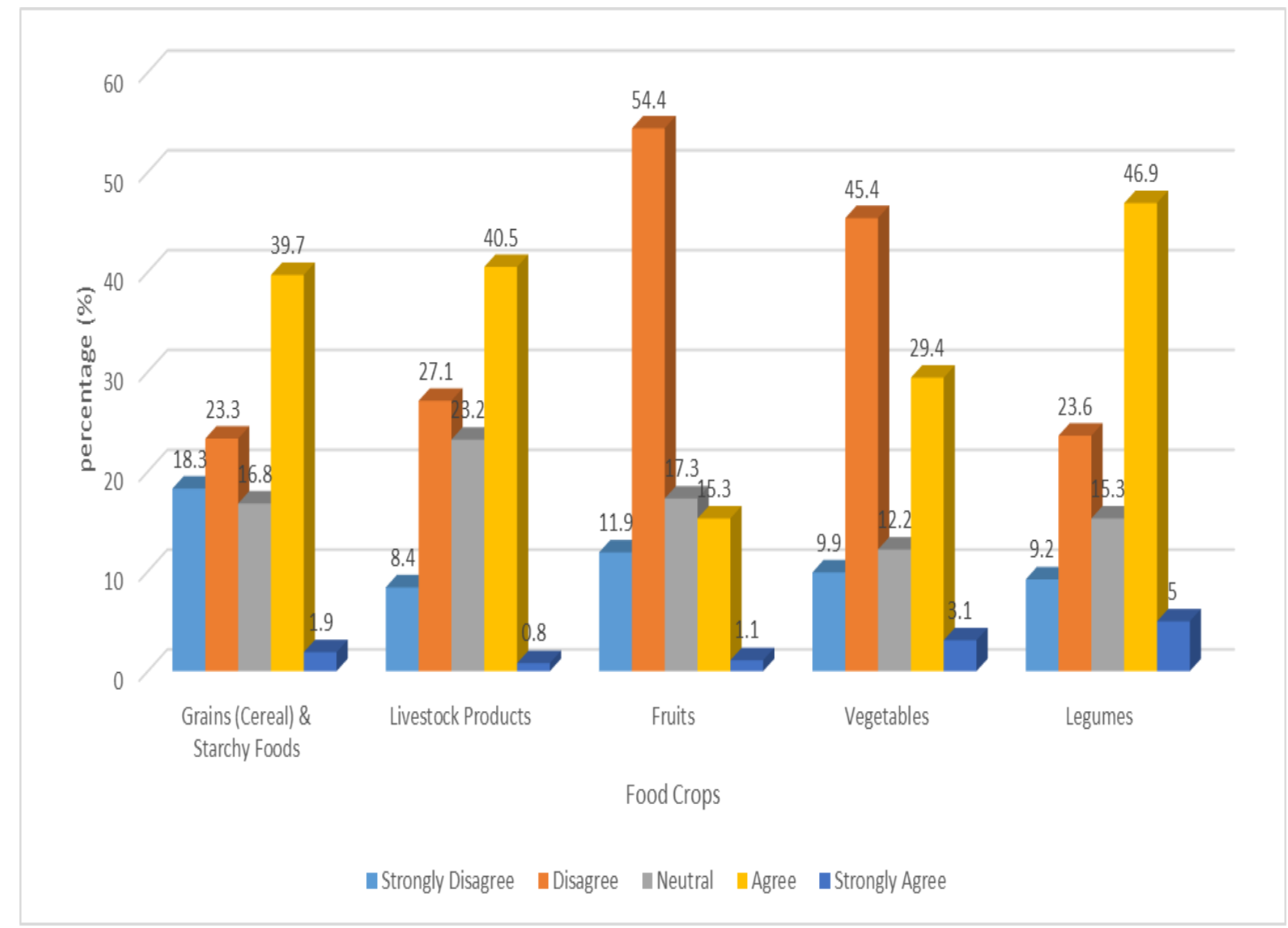

Fig 4: Opinion on post-harvest losses due to pandemic

Determination of appropriate mitigation measures on food security due to impacts of COVID-19 pandemic

Food access can be impacted upon through reduced household purchasing by the COVID-19 pandemic. The disruption of agricultural production which impacts on government capacities to protect the vulnerable populations could affect food availability. Other impacts include political instability and conflict dynamics (FAO \& WFP, 2020). Locals relied on social distancing, curfew, closure of food and drink outlets, home confinement and lockdown (Mattioli et al., 2020). The impacts of the pandemic on agriculture are diverse and their severity depends on the ability of the government to provide adequate social safety nets Depending on the need, various measures can be employed in synergy to boost agricultural production. To determine ways to improve agriculture in the study area, residents were asked to propose appropriate ways in which agricultural productivity could be improved. A number of options that have been used elsewhere during pandemics were floated and the household heads gave their opinion as shown in figure 5. 


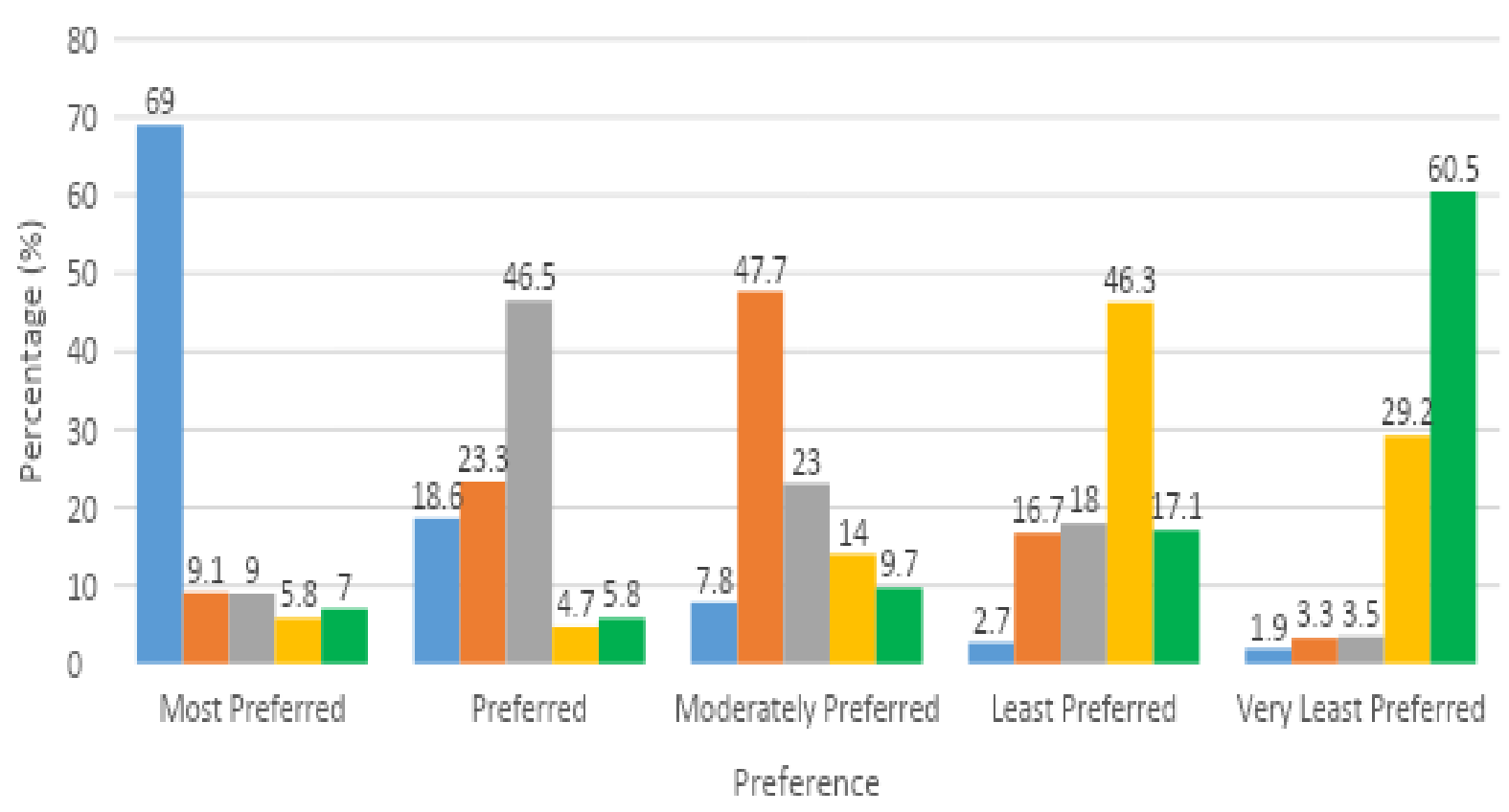

Provision of Credit/Lending

Proper Marketing Facilities

Supply of Quality Inputs

Agriculture Extension Services

Development of Small Scale Industries

Fig 5: Food security mitigation measures due to Pandemic

Provision of credit or lending as the most preferred (69\%) way of boosting agricultural production during the COVID-19 era. Supply of quality inputs and proper marketing was rated as preferred and moderately preferred by $46.5 \%$ and $47.7 \%$ respectively. Development of small-scale industries and agricultural extension services were rated as very least preferred by $60.5 \%$ and $29.2 \%$ of the respondents respectively. From previous findings, care should be taken to ensure that the pandemic does not impact on the six dimensions of food security that is availability, access, utilization, stability, agency and sustainability. Table 5 shows the results on Chi-Square tests on the relationship between price changes and ability to purchase food. 
Table 5: Relationship between price change and inability to purchase food

\begin{tabular}{lllll}
\hline Agricultural Product & Number of times used & $\chi^{2}$ & Df & P \\
\hline Cereals and starch & 214 & 132.488 & 6 & 0.000 \\
Livestock Products & 16 & 22.543 & 6 & 0.001 \\
Fruits & 10 & 27.928 & 6 & 0.000 \\
& & & & \\
$\quad$ Vegetables & 274 & 74.066 & 6 & 0.000 \\
& 214 & 40.825 & 6 & 0.000 \\
\hline
\end{tabular}

$\alpha=0.05$

There was a significant relationship between price change and respondent's inability to purchase food products. An increase in food prices denied the local access to food during the pandemic period as a result of many compounding factors that led to the highly uneven food prices both locally and internationally exacerbating hunger (Clapp \& G. Moseley, 2020). The relationship between price change and the inability to purchase food products was significant in the study area for grains (cereals \& starchy foods), livestock products, fruits, vegetables and legumes in the study area signifying how the COVID-19 pandemic had affected food security in the study area. These factors also triggered other secondary effects impacting on food security and nutrition altering food environments hence putting agricultural livelihoods at a risk.

\section{CONCLUSION AND RECOMMENDATIONS}

The COVID-19 pandemic has exposed weakness in the food supply chain including trans boundary restrictions on movement of food across nations, which threaten food security and nutrition. To avert the numerous food crises because of the secondary effects of the pandemic and safeguard vulnerable members of our community, governments, NGOs and corporations must embrace the need to work towards a common goal of ensuring food is accessible to those who need at fair prices. This can be achieved by coming up with and maintaining the existent humanitarian food and nutrition support programmes, education of vulnerable farming communities, promoting flexible operations for instance financing amidst the pandemic, avoid at all cost interruptions to essential food supply.

\section{ACKNOWLEDGEMENT}

The authors acknowledge the National Research Fund (Project No. 046/2018) for financial support for the study through the Annual Research Grants.

\section{REFERENCES}

[1] Barrett, C. B. (2020). Actions now can curb food systems fallout from COVID-19. Nature Food, 1-2.

[2] Battersby, J. (2020). South Africa's lockdown regulations and the reinforcement of anti-informality bias. Agriculture and Human Values, 1.
[3] Béné, C. (2020). Resilience of local food systems and links to food security-A review of some important concepts in the context of COVID-19 and other shocks. Food Security, 1-18.

[4] Chepwambok, L.Adede, W. O. Mugalavai, V.K. \& Onkware, A.O. (2020). Utilization of post-harvest technologies for improved food security: case of maize and mangoes among smallholder farmers in Kerio valley, Kenya. International Journal of Agriculture and Environmental Research. 06(03): 450-466 DOI: 10.46609/IJAER.2020.v06i03.010

[5] Clapp, J., \& G. Moseley, W. (2020). This food crisis is different: COVID19 and the fragility of the neoliberal food security order. The Journal of Peasant Studies, 1-25. https://doi.org/10.1080/03066150.2020.1823838

[6] Clapp, J., \& Moseley, W. G. (2020). This food crisis is different: COVID19 and the fragility of the neoliberal food security order. The Journal of Peasant Studies, 47(7), https://doi.org/10.1080/03066150.2020.1823838

[7] Committee on World Food Security. (2020). Impacts of COVID-19 on food security and nutrition: Developing effective policy responses to address the hunger and malnutrition pandemic. 24.

[8] Ekumah, B., Armah, F. A., Yawson, D. O., Quansah, R., Nyieku, F. E., Owusu, S. A., Odoi, J. O., \& Afitiri, A.-R. (2020). Disparate on-site access to water, sanitation, and food storage heighten the risk of COVID-19 spread in Sub-Saharan Africa. Environmental Research, 189, 109936 https://doi.org/10.1016/j.envres.2020.109936

[9] Espitia, A., Rocha, N., \& Ruta, M. (2020). Covid-19 and food protectionism: The impact of the pandemic and export restrictions on world food markets.

[10] FAO. (2020a). Coronavirus disease 2019 (COVID-19) | Addressing the impacts of COVID-19 in food crises: April-December 2020, May update, FAO's component of the Global COVID-19 Humanitarian Response Plan. 42.

[11] FAO. (2020b). COVID-19: Our hungriest and most vulnerable communities face "a crisis within a crisis": FAO in Emergencies. http://www.fao.org/emergencies/fao-in-action action

[12] FAO. (2020c). Food Outlook-June 2020 http://www.fao.org/3/ca9509en/ca9509en.pdf).

[13] FAO. (2020d). Gendered impacts of COVID-19 and equitable policy responses in agriculture, food security and nutrition. Policy brief. http://www.fao.org/policy-support/toolsand-publications/resourcesdetails/en/c/1276740/

[14] FAO, \& WFP. (2020a). FAO-WFP early warning analysis of acute food insecurity hotspots. FAO and WFP. https://doi.org/10.4060/cb0258en

[15] FAO, \& WFP. (2020b). FAO-WFP early warning analysis of acute food insecurity hotspots-July 2020-World. ReliefWeb. https://reliefweb.int/report/world/fao-wfp-early-warning-analysis-acutefood-insecurity-hotspots-july-2020

[16] Gerard, F., Imbert, C., \& Orkin, K. (2020). Social protection response to the COVID-19 crisis: Options for developing countries. Oxford Review of Economic Policy, 36(Supplement_1), S281-S296.

[17] GoK (2017). Elgeyo Marakwet County Integrated Development Plan 2018 2022. Nairobi: Government Printers

[18] HLPE. (2020). Food Security and Nutrition: Building a Global Narrative towards 2030. Report 15. Rome, HLPE. http://www.fao.org/3/ca9731en/ca9731en.pdf 
[19] ILO, I. L. O. (I. (2020). COVID-19 and the world of work. Fifth edition. ILO Monitor. 30 June 2020.https://www.ilo.org/wcmsp5/groups/public/@dgreports/@dcomm/doc uments/briefingnowcms_749399.pdf).

[20] KNBS. (2019). 2019 KENYA POPULATION AND HOUSING CENSUS POPULATION BY COUNTY AND SUB COUNTY - Kenya Data Portal. https://kenya.opendataforafrica.org/msdpnbc/2019-kenya-population-andhousing-census-population-by-county-and-sub-county?county=1002230elgeyo-marakwet

[21] Laborde, D., Martin, W., Swinnen, J., \& Vos, R. (2020). COVID-19 risks to global food security. Science, 369(6503), 500-502. https://doi.org/10.1126/science.abc4765

[22] Lewis, L. (2020, April 3). Coronavirus serves up a surplus of Wagyu beef. https://www.ft.com/content

[23] Mattioli, A. V., Sciomer, S., Cocchi, C., Maffei, S., \& Gallina, S. (2020). Quarantine during COVID-19 outbreak: Changes in diet and physical activity increase the risk of cardiovascular disease. Nutrition, Metabolism and Cardiovascular Diseases, 30(9), 1409-1417.

[24] McLaren, H. J., Wong, K. R., Nguyen, K. N., \& Mahamadachchi, K. N. D. (2020). Covid-19 and Women's Triple Burden: Vignettes from Sri Lanka, Malaysia, Vietnam and Australia. Social Sciences, 9(5), 87.

[25] Micha, R., Mannar, V., Afshin, A., Allemandi, L., Baker, P., Battersby, J., Bhutta, Z., Chen, K., Corvalan, C., \& Di Cesare, M. (2020). 2020 Global nutrition report: Action on equity to end malnutrition.

[26] Moseley, W. G. (2020). The Geography of COVID-19 and a Vulnerable Global Food System.

[27] Power, K. (2020). The COVID-19 pandemic has increased the care burden of women and families. Sustainability: Science, Practice and Policy, 16(1), $67-73$

[28] Rakotoarisoa, M. A., Iafrate, M., \& Paschali, M. (2011). Why Has Africa Become a Net Food Importer? Explaining Africa Agricultural and Food Trade Deficits: Vol. null (null, Ed.).

[29] Reardon, T., \& Swinnen, J. (2020). COVID-19 and resilience innovations in food supply chains. IFPRI Book Chapters, 132-136.

[30] Roussi, A. (2020). Kenya farmers face uncertain future as Covid-19 cuts exports to EU. The Financial Times. Available at Https://www. Ft. Com/Content

[31] Tamru, S., Hirvonen, K., \& Minten, B. (2020). Impacts of the COVID-19 crisis on vegetable value chains in Ethiopia. IFPRI Book Chapters, 81-83.
[32] Torero, M. (2020). Prepare food systems for a long-haul fight against COVID-19. IFPRI Book Chapters, 118-121.

[33] UN, (2020). The Impact of COVID-19 on Food Security and Nutrition. June.

https://reliefweb.int/sites/reliefweb.int/files/resources/sg_policy_brief_on_c ovid_impact_o n_food_security.pdf).

[34] UNCTAD. (2020). Ld Investment Report 2020: International production beyond the pandemic. Geneva, UN https://unctad.org/en/PublicationsLibrary/gds_tdr2019_covid2_en.pdf).

[35] WFP, (2020). Global Monitoring of School Meals during COVID-19 Closures. https://cdn.wfp.org/2020/school-feeding-map

[36] WHO. (2020a). Clinical care for severe acute respiratory infection: Toolkit: COVID-19 adaptation. World Health Organization. Regional Office for Europe.

[37] WHO(2020b). Gender and COVID-19. Advocacy Brief. 14 May 2020 https://www.who.int/puFocus blications/i/item/gender-and-covid-19.

[38] World Bank. (2020). Global Economic Prospects, June 2020. Washington, DC, World Bank. https://www.worldbank.org/en/publication/globaleconomicprospects\#overview

[39] Yaffe-Bellany, D., \& Corkery, M. (2020). Dumped milk, smashed eggs, plowed vegetables: Food waste of the pandemic. The New York Times.

[40] Yamane, T. (1967). Elementary sampling theory.

\section{AUTHORS}

First Author - Ouma, Peter O., Center for Teacher Education, School of Education, University of Eldoret Box 1125 Eldoret Second Author - Ouma Robinson, Department of Business Studies, Rongo University, Kenya

Third Author - Mugalavai, Violet K., School of Agriculture, Department of Family Consumer Sciences, University of Eldoret, Kenya.

Fourth Author - Onkware, Augustino O, School of Science, Rongo University, Kenya.

Corresponding email:

pouma@uoeld.ac.ke/ookouma@gmail.com 